\title{
Effects of Diethyl Ether Introduction in Emissions and Performance of a Diesel Engine Fueled with Biodiesel-Ethanol Blends
}

\author{
Márcio Carvalho ${ }^{1,2, *(1)}$, Felipe Torres ${ }^{1,3}$, Vitor Ferreira ${ }^{4}$, Júlio Silva ${ }^{5} \mathbb{C}$, Jorge Martins ${ }^{6}$ and \\ Ednildo Torres ${ }^{7}$ \\ 1 Polytechnic School, Industrial Engineering Postgraduate Program, Federal University of Bahia, \\ Rua Aristides Novis, 2, Federação, Salvador 40210-630, Brazil; ftorres@ufrb.edu.br \\ 2 Multidisciplinary Campus of Bom Jesus da Lapa, Federal University of West of Bahia, \\ Av. Manoel Novaes, 1064, Bom Jesus da Lapa 47600-000, Brazil \\ 3 Department of Mechanical Systems, Federal University of Reconcavo of Bahia, Rua Rui Barbosa, 710, Centro, \\ Cruz das Almas 44380-000, Brazil \\ 4 Institute of Science, Technology and Innovation, Federal University of Bahia, Rua do Telegráfo S/N, \\ Camaçari 42809-000, Brazil; vitorpf@ufba.br \\ 5 Department of Mechanical Engineering, Federal University of Bahia, Rua Aristides Novis, 2, Federação, \\ Salvador 40210-630, Brazil; julio.silva@ufba.br \\ 6 Department of Mechanical Engineering, Minho University, Av. da Universidade, Guimarães 4800-058, \\ Portugal; jmartins@dem.uminho.pt \\ 7 Department of Chemical Engineering, Federal University of Bahia, Rua Aristides Novis, 2, Federação, \\ Salvador 40210-630, Brazil; ednildo@ufba.br \\ * Correspondence: marcio.carvalho@ufob.edu.br
}

Received: 2 June 2020; Accepted: 29 June 2020; Published: 23 July 2020

\begin{abstract}
Biofuels provide high oxygen content for combustion and do modify properties that influence the engine operation process such as viscosity, enthalpy of vaporization, and cetane number. Some requirements of performance, fuel consumption, efficiency, and exhaust emission are necessary for the validation of these biofuels for application in engines. This work studies the effects of the use of diethyl ether (DEE) in biodiesel-ethanol blends in a DI mechanical diesel engine. The blends used in the tests were B80E20 (biodiesel 80\%-ethanol 20\%) and B76E19DEE5 (biodiesel 76\%-ethanol 19\%-DEE 5\%). Fossil diesel (D100) and biodiesel (B100) were evaluated as reference fuels. The results revealed similar engine efficiencies among tested fuels at all loads. The use of B100 increased CO and $\mathrm{NO}_{\mathrm{x}}$ and decreased THC compared to D100 at the three loads tested. B80E20 fuel showed an increase in $\mathrm{NO}_{\mathrm{x}}$ emission in comparison with all fuels tested, which was attributed to higher oxygen content and lower cetane number. THC and CO were also increased for B80E20 compared to B100 and D100. The use of B76E19DEE5 fuel revealed reductions in $\mathrm{NO}_{x}$ and $\mathrm{CO}$ emissions, while THC emissions increased. The engine efficiency of B76E19DEE5 was also highlighted at intermediate and more elevated engine load conditions.
\end{abstract}

Keywords: Biodiesel; diesel engines; diethyl ether; ethanol; biofuels; emissions

\section{Introduction}

The growing concern over climate change and fossil fuel dependency has increased visibility for renewable energy sources [1]. Biofuels have been identified as promising renewable fuels, in particular, when originated from waste feedstock and non-edible plant species [2].

The use of alternative fuels in compression ignition (CI) engines should be evaluated in many terms, as exhaust emissions, fuel stability, availability, distribution, and impacts on engine durability [3]. 
Among biofuels, biodiesel is considered a promisor fuel substitute due to similar results of engine performance and efficiency with those obtained with neat diesel. However, the elevated viscosity, higher cloud point, and pour point properties are adverse factors that can result in solidification during cold weather, causing clogging in filter and fuel lines that lead to engine damage [4]. The addition of less viscous fuels such as ethanol or diethyl ether (DEE) into biodiesel or diesel-biodiesel blends can improve the fuel spray characteristics in the combustion chamber and avoid clogging problems [5-7]. One of the main objectives of the research work with alternative fuels focused on optimizing the fuel blend based on fuel properties like kinematic viscosity, density, cloud point, and pour point [8]. Besides that, studies considering the feasibility of blending biofuels with fossil fuels in terms of heating and evaporation are important. In this context, Al-Esawi, Qubeissi, and Kolodnytska [9] reported that pure biodiesel and pure ethanol had $11.7 \%$ and $43.3 \%$ less droplet lifetime than pure diesel, ascribed to the fact that ethanol and biodiesel had higher vapor pressures than diesel. The droplet lifetime also decreased in relation to diesel when fractions of biodiesel, ethanol, or both fuels were used in blends with diesel. However, the differences were less than $2 \%$. A similar lifetime study was carried out by $\mathrm{Al}$ Qubeissi et al. [10] using the gasoline fossil in comparison to ethanol. However, the results showed that, in this case, gasoline had an average time of about $34 \%$ less than pure ethanol. A complementary study by Al-Esawi et al. [11] used E85 (85\% ethanol and 15\% fossil gasoline) in blends with diesel. Results showed that the droplet lifetime for pure diesel was longer than that for any blend. The difference reaches $49.5 \%$ for pure E85 and was about $6 \%$ for the blend E85 with 5\% of diesel.

The use of ethanol in blends with diesel is also justified by the percentage increase of biofuel in the blend and by technical issues, such as increased oxygen content and the possibility of reducing pollutant emissions, such as particulate matter and $\mathrm{NO}_{\mathrm{x}}$, simultaneously [6]. Some properties of ethanol, however, are adverse in terms of $\mathrm{CI}$ engine requirements. For example, its low cetane number (CN) makes it unfeasible to be used as the main fuel in CI engines. On the other hand, ethanol can be used blended with diesel or biodiesel and can result in the improvement of volumetric efficiency and reduction of particulate matter (PM) emission. In general, the low $\mathrm{CN}$ of ethanol induces a longer ignition delay, resulting in more premixed mixture and higher heat release rate (HRR) during combustion process [7]. However, the higher enthalpy of vaporization of ethanol produces a cooling effect that results in reduction of the global combustion temperature and consequently $\mathrm{NO}_{\mathrm{x}}$ formation decrease. In this way, opposite results regarding $\mathrm{NO}_{\mathrm{x}}$ emission due to ethanol addition can be found in literature. Results may vary according to blend composition, engine design, and method of application. Tutak et al. [12] developed a comparative study of the effect of the use of diesel-ethanol and biodiesel-ethanol blends on performance and emission characteristics of a diesel engine. The tests were conducted at a constant angle of diesel fuel injection, full load, and constant rotational speed (1500 rpm). Authors observed thermal efficiency increase using high ethanol content in diesel-biodiesel blends, while there was similar thermal efficiency in biodiesel-ethanol blends. Authors observed thermal efficiency increase using high ethanol content in diesel-biodiesel blends, while similar thermal efficiency in biodiesel-ethanol blends was observed. Emissions of total hydrocarbons (THC) and $\mathrm{NO}_{\mathrm{x}}$, however, were higher for the blends when compared with neat diesel and biodiesel. Yilmaz [13] observed a reduction in $\mathrm{NO}_{\mathrm{x}}$ emissions when using a blend of biodiesel $(85 \%)$ and ethanol $(15 \%)$ in comparison to diesel and biodiesel. The author attributed this result to the higher enthalpy of vaporization and the lower heating value (LHV) of the ethanol, which reduced the combustion temperature. Engine tests were developed at part-load and full-load conditions at a constant speed. In a study by Prbakaran and Viswanathan [14], blends of cottonseed oil methyl ester and anhydrous ethanol in 10\%, 30\%, and 50\% in volume were tested in a diesel engine at various loads. It was observed that $\mathrm{NO}_{\mathrm{x}}$ emission was reduced in blend containing 50\% ethanol, for all the loads, comparing to the fossil diesel and the other blends. The evaporation characteristic of B50E50 was reported as one of the reasons for the reduction of $\mathrm{NO}_{\mathrm{x}}$. The use of the blends B70E30 and B90E10, however, showed an increase in $\mathrm{NO}_{\mathrm{x}}$ at higher loads, which was attributed to combustion temperature increase by the additional oxygen content promoted by ethanol addition. Kandasamy et al. [15] observed that the use of $20 \%$ of ethanol in a B5 
blend ( $5 \%$ of esterified cotton seed methyl ester and $95 \%$ of neat diesel) decreased $\mathrm{NO}_{\mathrm{x}}$ and unburned hydrocarbon emissions at lower to medium speed range and increased thereafter.

The research work with alternative fuels focused on optimizing the fuel blend based on fuel properties like kinematic viscosity, density, cloud point, and pour point.

DEE appears as a potential additive to diesel-biodiesel-ethanol blends among oxygenated biofuels due to its chemical properties such as high cetane number $(>125)$, moderate energy density (similar to biodiesel), high oxygen content in its structure, low self-ignition temperature, prolonged flame duration, and adequate miscibility with diesel, biodiesel, and ethanol. In this context, DEE can be considered more suitable to be used for CI engines application than ethanol or methanol due to its higher CN and LHV [16]. Some research has been developed using DEE to improve ignition quality in blends composed by diesel and other feedstocks fuels. Lee and Kim [17] evaluated blends of diesel and DEE and results showed similar engine efficiency compared to diesel along with lower emissions of THC, $\mathrm{CO}$, and PM. However, $\mathrm{NO}_{\mathrm{x}}$ emissions were higher. The authors attributed the results to the shorter ignition delay and high oxygen content of the blends. Qi et al. [18] investigated the effects of ethanol and DEE as additives in a diesel-biodiesel blend. The tested fuels were B30 (30\% biodiesel and $70 \%$ diesel), BE-1 (5\% diethyl ether, $25 \%$ biodiesel, and 70\% diesel) and BE-2 (5\% ethanol, $25 \%$ biodiesel, and $70 \%$ diesel). Reduction in smoke and $\mathrm{CO}$ were observed with BE-1 and BE-2, while $\mathrm{NO}_{\mathrm{x}}$ was higher for BE-2 and HC was higher for BE-1 and BE-2 when compared to B30. Jeevanantham et al. [19] used DEE in blends with diesel-biodiesel in volumetric proportion of 5\% (D50B45DEE5) and 10\% (D50B40DEE10). Results showed that $\mathrm{NO}_{\mathrm{x}}$ emissions were reduced in all test conditions concerning the other fuels. The authors attributed the results to the significant cooling effect caused by the high enthalpy of vaporization of DEE. This work approaches the application of DEE in biodiesel-ethanol blends. The DEE was used toward enhancing the $\mathrm{CN}$, which was deteriorated as a result of ethanol introduction. In the literature, it is common to use blends with DEE, however, most part considering diesel in its composition. This work evaluates the performance and emissions of a light-duty naturally aspirated diesel engine with mechanical fuel injection using biodiesel, ethanol, and DEE. DEE is used as an additive to increase the $\mathrm{CN}$, which is deteriorated as a result of ethanol introduction. The tests were developed in a light-duty naturally aspirated diesel engine with mechanical fuel injection, evaluate the performance, efficiency, and exhaust emissions.

\section{Materials and Methods}

\subsection{Experimental Setup}

The engine used in the experiments was a four-stroke, two cylinders, direct fuel injected, and naturally aspirated diesel engine. The main characteristics of the engine are summarized in Table 1.

Table 1. Engine characteristics.

\begin{tabular}{cc}
\hline Engine Manufacturer & Agrale \\
\hline Model & M790 \\
Number of cylinders & 2 \\
Bore $\times$ Stroke & $90 \mathrm{~mm} \times 100 \mathrm{~mm}$ \\
Engine displacement & $1272 \mathrm{~cm}^{3}$ \\
Compression ratio & $18: 1$ \\
Maximum Brake Power $(\mathrm{kW})$ & $19.8 \mathrm{~kW}$ at $3000 \mathrm{rpm}$ \\
Maximum torque $(\mathrm{Nm})$ & $70 \mathrm{Nm}$ at $2250 \mathrm{rpm}$ \\
Injection type & Direct Injection. \\
\hline
\end{tabular}

The engine original specifications were kept constant throughout the tests.

Figure 1 shows a schematic diagram of the experimental setup that consists of a diesel engine coupled with a hydraulic dynamometer (Shenck D210), a gas analyzer for exhaust emission, HC meter, fuel tank, scale, high-pressure fuel pump, and K-type thermocouples for temperature measurement. 


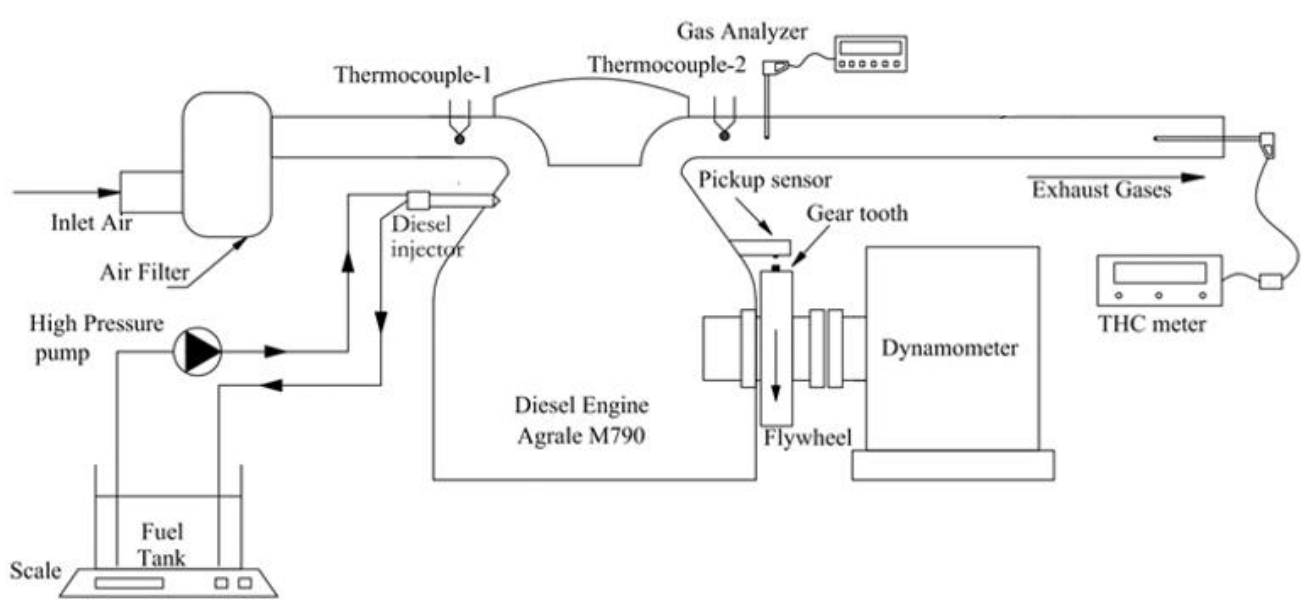

Figure 1. Schematic diagram of experimental setup.

Experimental tests were performed under three loads: $2.7 \mathrm{~kW}, 5.4 \mathrm{~kW}$, and $8.1 \mathrm{~kW}$, and engine speed was fixed at $1700 \mathrm{rpm}$. These loads correspond to $25 \%, 50 \%$, and $75 \%$ of the maximum brake power (BP) at the engine speed of $1700 \mathrm{rpm}$, using mineral diesel as a reference fuel. These loads were chosen since engine maximum load is not achievable with blends of reduced LHV.

The amount of fuel injected varied for each fuel tested due to the difference in LHV between the fuels (Table 2). This control was performed by varying the acceleration in the high-pressure fuel injection pump.

Table 2. Compositions of tested fuels.

\begin{tabular}{cccccc}
\hline Fuel & Diesel & B100 & Ethanol & DEE & LHV (MJ/kg) \\
\hline D100 & $100 \%$ & $0 \%$ & $0 \%$ & $0 \%$ & 42.50 \\
B100 & $0 \%$ & $100 \%$ & $0 \%$ & $0 \%$ & 37.45 \\
B80E20 & $0 \%$ & $80 \%$ & $20 \%$ & $0 \%$ & 35.80 \\
B76E19DEE5 & $0 \%$ & $76 \%$ & $19 \%$ & $5 \%$ & 35.84 \\
\hline
\end{tabular}

\subsection{Fuels Characteristics}

Evaluated blends were prepared using soybean biodiesel (B100), ethanol (purity of 99.3\%), and diethyl-ether (DEE, purity of 99.7\%). Diesel fossil pure (D100, maximum 10 ppm of sulfur) and pure biodiesel were tested as reference. The main characteristics of the fuels are depicted in Table 3.

Table 3. Properties of original fuels.

\begin{tabular}{lcccc}
\hline \multicolumn{1}{c}{ Properties } & Diesel & Biodiesel & Ethanol & DEE \\
\hline Formula & $\mathrm{C}_{10} \mathrm{H}_{18}$ & $\mathrm{C}_{18} \mathrm{H}_{34} \mathrm{O}_{2}$ & $\mathrm{C}_{2} \mathrm{H}_{6} \mathrm{O}$ & $\mathrm{C}_{4} \mathrm{H}_{10} \mathrm{O}$ \\
Oxygen content, $(\%)$ & 0 & 10.8 & 34.7 & 21.6 \\
Density $@ 20^{\circ} \mathrm{C},\left(\mathrm{g} / \mathrm{m}^{3}\right)$ & 0.840 & 0.878 & 0.786 & 0.713 \\
Viscosity @ $40^{\circ} \mathrm{C},(\mathrm{cSt})$ & 3.30 & 4.95 & 1.20 & 0.23 \\
Flash point, $\left({ }^{\circ} \mathrm{C}\right)$ & 96 & 158 & 15 & -45 \\
Cetane number & 46 & 56 & 6.5 & 120 \\
Lower heating value, $(\mathrm{MJ} / \mathrm{kg})$ & 42.50 & 37.45 & 28.40 & 36.87 \\
Enthalpy of evaporation, $(\mathrm{kJ} / \mathrm{kg})$ & 260 & 200 & 836 & 356 \\
\hline
\end{tabular}

An IKA C2000 bomb calorimeter was employed to determine the lower heating value based on the standard ASTM-D240-87. The fuel density was measured using a DMA-5000 densimeter, while samples viscosity was measured by a model $P$ capillarity viscometer. Table 2 shows the composition of single fuels, biodiesel-ethanol, and biodiesel-ethanol-DEE along with their volumetric compositions and LHV. 
The LHV was predicted based on the volumetric fractions, density, and energy fractions of each blend component. This methodology was also used by Al-Esawi, Al Qubeissi, and Kolodnytska [9].

The stability of the B76E19DEE5 blend was evaluated under the test temperatures to certify that no fuel would be lost by evaporation.

\subsection{Instrumentation}

Fuel mass flow rate was obtained by gravimetric method using a digital scale while fuel consumption was evaluated under five cycles of measurement with a sampling time of 30 minutes. Exhaust gas emissions of $\mathrm{CO}, \mathrm{NO}_{\mathrm{x}}$, and THC were assessed using two gas analyzers under an average of 30 measurements for each fuel. The main characteristics and uncertainty of the employed instruments are shown in Table 4.

Table 4. Properties of the main instruments.

\begin{tabular}{|c|c|c|c|c|}
\hline Measure & Instrument & Manufacturer (model) & Range & Uncertainty \\
\hline Ambient humidity & Digital hygrometer & Icel (HT-208) & 0 to $100 \%$ & $\pm 3 \%$ \\
\hline Fuel consumption & Digital scale & Mettler Toledo (9094) & 0 to $15 \mathrm{~kg}$ & $\pm 2 \%$ \\
\hline Exhaust Gas $\left(\mathrm{NO}_{x} ; \mathrm{CO}\right)$ & Gas analyzer & COSA (Optima 7) & 0-1000 ppm & $\pm 5 \%$ \\
\hline Exhaust Gas (THC) & Gas analyzer & NAPRO (PC Multigas) & 0-2000 ppm & $\pm 5 \%$ \\
\hline
\end{tabular}

In order to enhance the confidence level of the experiments, the tests were carried out under similar system conditions for all fuels, such as engine temperature and weather temperature between $\left(29 \pm 2{ }^{\circ} \mathrm{C}\right)$ and humidity $(55 \pm 8 \%)$.

\section{Results and Discussions}

\subsection{Engine Performance}

\subsubsection{Brake Specific Fuel Consumption (BSFC)}

Brake specific fuel consumption may be defined as a ratio between fuel mass flow rate and engine brake power, which usually depends on the volumetric fuel injection system and fuel properties (e.g., density, calorific value, and viscosity). Figure 2 outline an increase in BSFC when the engine operates with biofuels compared to mineral diesel (D100), which may be explained by the lower LHV of biofuels blends, as shown in Table 2.

It is also observed that as loads increases, BSFC decreases for all fuels due to the higher engine efficiency at high engine loads [20].

When engine operated with B100 there was an increase in BSFC of about $14 \%$ on average, under the three loads, in comparison with D100, while the difference in LHV was only $12 \%$ lower for B100 in comparison with D100. Thus, it is possible to infer a slight reduction in engine efficiency when B100 is used. Besides, the higher viscosity of B100 leads to an increase in BSFC. Higher viscosity alters fuel jet atomization, increasing the average diameter and density of fuel droplets while reduces combustion efficiency [21]. When compared to B100, the biodiesel-ethanol (B80E20) blend has shown an increase in BSFC of $5.3 \%, 4.2 \%$, and $3 \%$ at loads of $2.7 \mathrm{~kW}, 5.4 \mathrm{~kW}$, and $8.1 \mathrm{~kW}$, respectively. The further increase of fuel consumption of B80E20 is due to a reduction in LHV of about $4.4 \%$ for the blend, which occurred as a result of the introduction of ethanol, which explains the increase in BSFC. Furthermore, a greater difference can be observed at lower loads due to lower combustion temperatures [22], whereas the high ethanol enthalpy of vaporization induces a reduction in combustion temperature and thus combustion efficiency decreases. A slight decrease in BSFC was observed in the blend with diethyl ether (B76E19DEE5) in concerning to B80E20 blend, under all tested conditions. This reduction can be attributed to the short increment in LHV of about $1.2 \%$. However, other factors also contribute to improving combustion quality for this blend, such as higher $\mathrm{CN}$ and the high oxygen content [8]. 


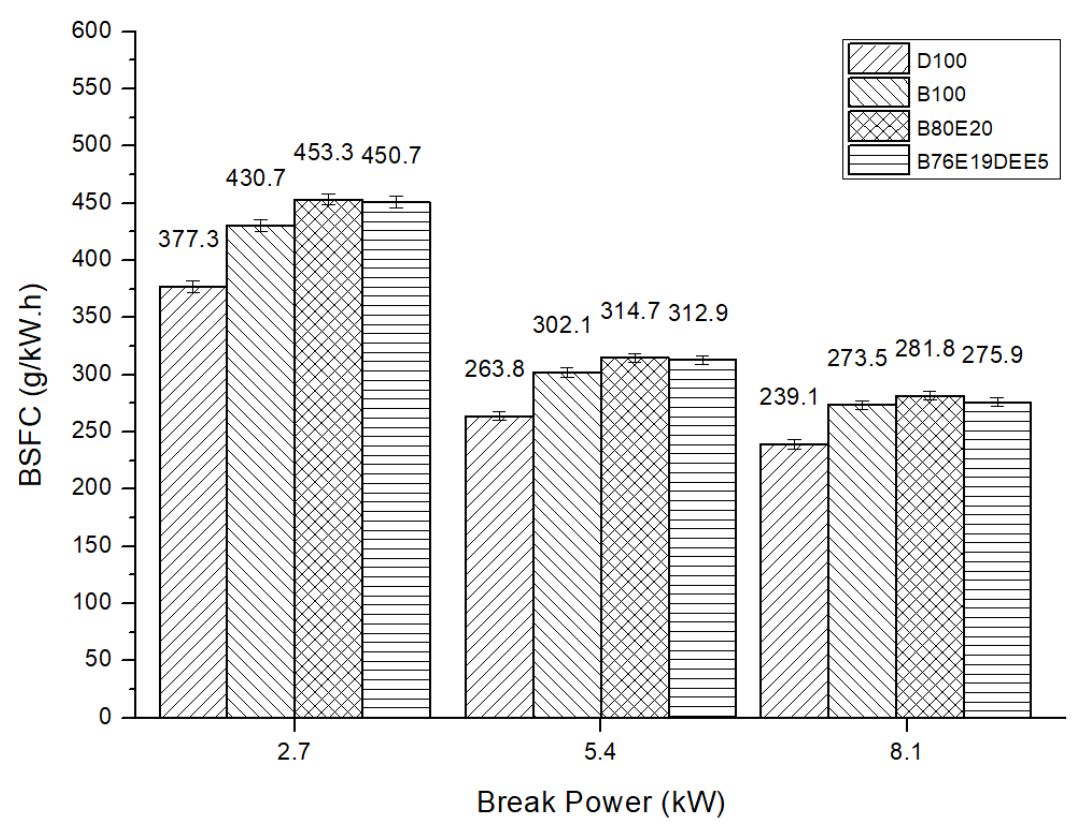

Figure 2. The variation of brake specific fuel consumption with respect to the engine load.

\subsubsection{Brake Specific Energy Consumption (BSEC)}

Another way of evaluating the performance of the fuels tested is by using the BSEC. While BSFC represents a measure of fuel mass consumption, BSEC allows a view of the energy consumption of the fuels, in accordance with the engine brake power. The results of the BSEC obtained in the experiments are presented in Figure 3.

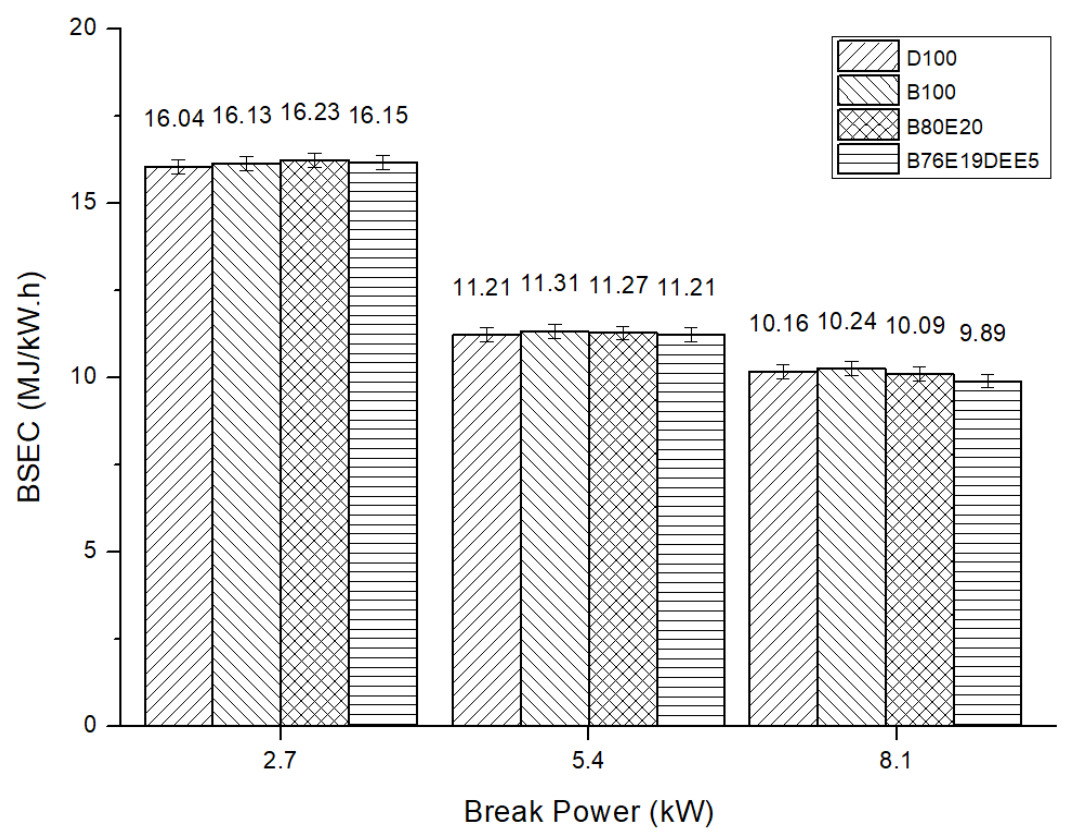

Figure 3. The variation of brake specific energy consumption with respect to the engine load.

Figure 3 shows relatively small differences between the fuel samples tested. This similarity of results shows that the performance of the proposed fuel blends is consistent with the conventional diesel of the engine design. Considering the test conditions, in the lowest load, $2.7 \mathrm{~kW}$, the lowest BSEC value can be observed with the D100 and the highest value for the B80E20 fuel. This can be attributed to the cooling effect of the chamber and, therefore, to the increase of the delay of the start of 
the ignition using B80E20. These factors are due to the high enthalpy of evaporation and low $\mathrm{CN}$ of the blend B80E20, which has more influence at the low load condition due to the lower temperatures in the chamber wall and in the residual gases of the combustion [12,15]. Regarding the D100, its better results can be explained by adequate properties of the D100 in accordance with the design parameters of the diesel engine, providing adequate conditions for burning [20].

At the highest load, $8.1 \mathrm{~kW}$, an improvement of the BSEC was observed using B80E20 with respect to D100. This can be explained due to the higher temperatures in the chamber and in the residual gases of combustion in that condition. In addition, the fuel oxygen content improves the fuel-burning quality $[8,12,15]$.

Considering B76E19DEE5, the presence of DEE reduced the BSEC compared to B80E20 in all test conditions. At the $8.1 \mathrm{~kW}$ load, B76E19DEE5 presented the lowest BSEC with respect to the other fuels tested. These results can be attributed to the improvement of the burning process due to the oxygen content and the elevation of the $\mathrm{CN}$ of the blend with DEE [16-18].

\subsubsection{Engine Efficiency}

Engine efficiency may be defined as the useful energy output of the engine as a function of fuel heat energy. As shown in Figure 4, higher loads present increased engine efficiency as a result of a more adequate air/fuel ratio and enhanced mechanical efficiency [20].

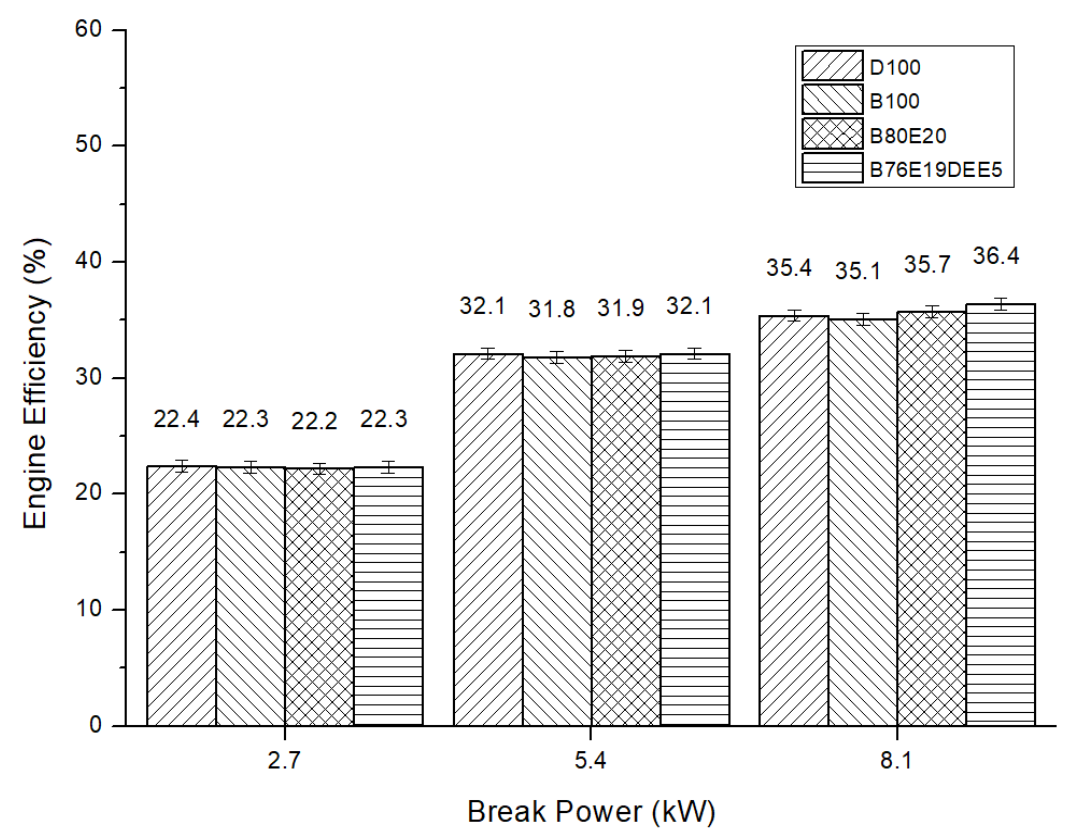

Figure 4. The variation of engine efficiency with respect to the engine load.

A slight reduction of about $0.7 \%$ on average, under all loads, was observed in engine efficiency while using B100 with respect to D100. These variations can be attributed to differences in viscosity and density, which influence atomization and decrease combustion efficiency [21]. This can be confirmed by a more significant reduction in BSFC in comparison to that observed for the LHVs when B100 replaces D100. The results are consistent with some studies in the literature [22-25] despite other studies show increased efficiency while the engine operates with blends of biodiesel and diesel. It can be discussed that when biodiesel raw material presents low viscosity, the oxygen in the biodiesel molecule and the higher cetane number than diesel can improve the combustion characteristic [26-28]. On the other hand, addition of ethanol to the blend decreases viscosity, LHV, and CN in comparison with B100, although oxygen content increases. When related to B100, the blend B80E20 presents an increase in efficiency of $0.4 \%$ and $1.6 \%$ at $5.4 \mathrm{~kW}$ and $8.1 \mathrm{~kW}$ loads, respectively. The lower viscosity of B80E20 improves atomization and provides better evaporation and air-fuel mixing, hence improving 
combustion efficiency. In addition, higher oxygen content causes faster combustion [7,25,29]. At $2.7 \mathrm{~kW}$, similar efficiencies values were observed. Introduction of diethyl ether (B76E19DEE5) revealed a slight increase of $0.5 \%$ in engine efficiency under $2.7 \mathrm{~kW}$ and $5.4 \mathrm{~kW}$ of engine loads in comparison with B80E20 fuel, whereas under $8.1 \mathrm{~kW}$ the increase was about 2\%. DEE addition to the blend promotes a reduction in viscosity, which facilitates fuel atomization, and due to the higher $\mathrm{CN}$ of diethyl ether, it decreases the ignition delay [18].

\subsection{Emissions}

\subsection{1. $\mathrm{NO}_{\mathrm{x}}$ Emissions}

$\mathrm{NO}_{\mathrm{x}}$ emissions for the studied blends compared to D100 and B100 are shown in Figure 5. It has been widely discussed that as loads increases, $\mathrm{NO}_{\mathrm{x}}$ exhaust emission increases due to higher temperatures in the combustion chamber that increases the $\mathrm{NO}_{\mathrm{x}}$ formation by thermal mechanism [30-32].

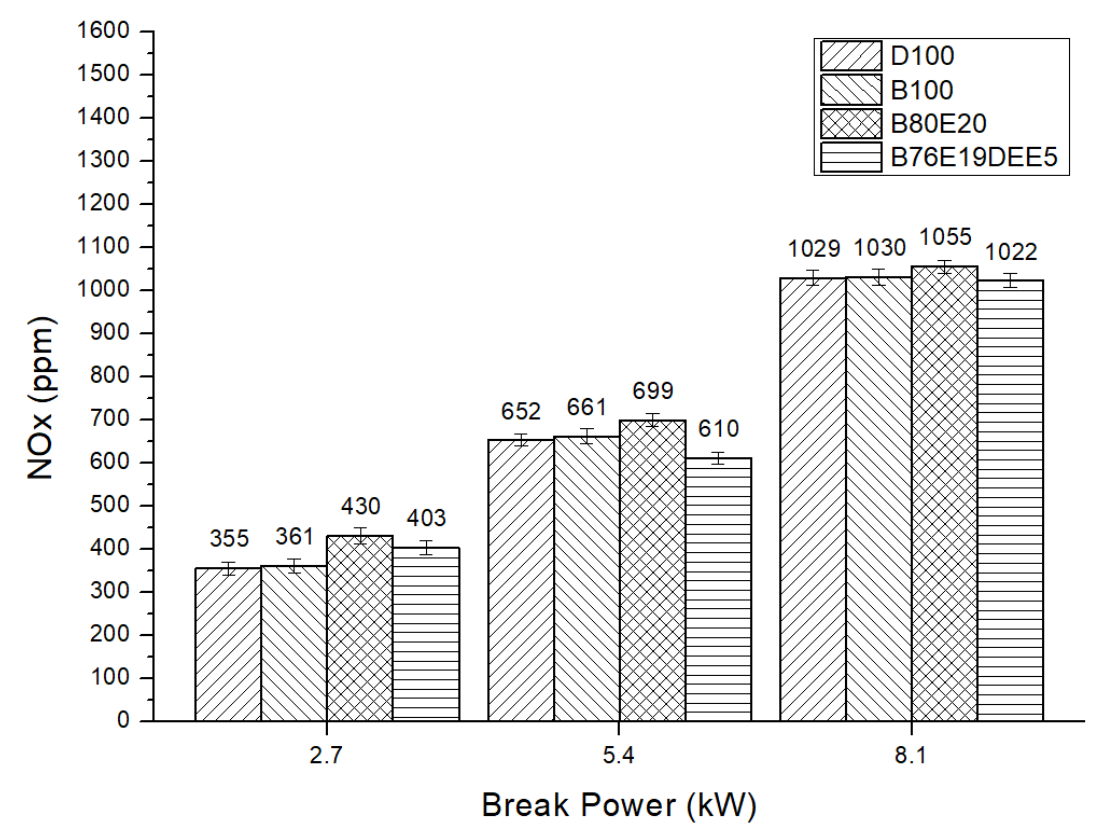

Figure 5. The variation of $\mathrm{NO}_{\mathrm{x}}$ emissions with respect to the engine load.

B100 showed minor increases in $\mathrm{NO}_{\mathrm{x}}$ emissions in comparison with fossil diesel. This increase can be explained primarily by the oxygen content in the biodiesel molecule, which increases oxygen availability and combustion temperatures [33]. Besides, the higher bulk modulus of biodiesel can advance its injection increasing the preparation time of the fuel-air mixture, which increases combustion pressure and temperature, thus, contributing to $\mathrm{NO}_{x}$ formation [33].

B80E20 fuel resulted in an increase in $\mathrm{NO}_{x}$ emissions compared to the other tested fuels. These results can be attributed to the lower $\mathrm{CN}$, which prolongs the premix formation time and increases heat release ratio (HRR) in the initial phase of combustion, thus higher temperatures and $\mathrm{NO}_{\mathrm{x}}$ emission are obtained $[34,35]$. Furthermore, the high oxygen content of ethanol (Table 2) contributes to $\mathrm{NO}_{\mathrm{x}}$ formation [8]. The high oxygen content of the fuel has a positive effect on the combustion since the oxygen presented in the fuel is more active when compared to the molecular oxygen contained in the air [36]. Even though higher oxygen content produces greater combustion efficiency, higher temperatures increase $\mathrm{NO}_{x}$ formation [37,38].

The use of DEE (B76E19DEE5) revealed a significant reduction in $\mathrm{NO}_{\mathrm{x}}$ emission. In comparison with the B80E20 blend, the reduction was approximately $6 \%, 13 \%$, and $3 \%$, at $2.7 \mathrm{~kW}, 5.4 \mathrm{~kW}$, and $8.1 \mathrm{~kW}$ engine loads, respectively. Besides, under $5.4 \mathrm{~kW}$ and $8.1 \mathrm{~kW}$, the B76E19DEE5 blend has shown the lowest $\mathrm{NO}_{\mathrm{x}}$ emission among all fuels tested. These results can be attributed to two main factors 
that are mainly related to fuel characteristics. Firstly, the higher $\mathrm{CN}$, which decreases the ignition delay and the premix formation time, thus reducing the combustion pressure and temperature peaks. Furthermore, the enthalpy of vaporization of the blend is also elevated, which reduces combustion temperature, thus, reducing $\mathrm{NO}_{\mathrm{x}}$ emissions [8].

\subsubsection{CO Emissions}

Figure 6 shows the $\mathrm{CO}$ emission for the fuels tested. $\mathrm{CO}$ emissions increased for higher engine load due to lower air-fuel ratios presented in the combustion phase [37].

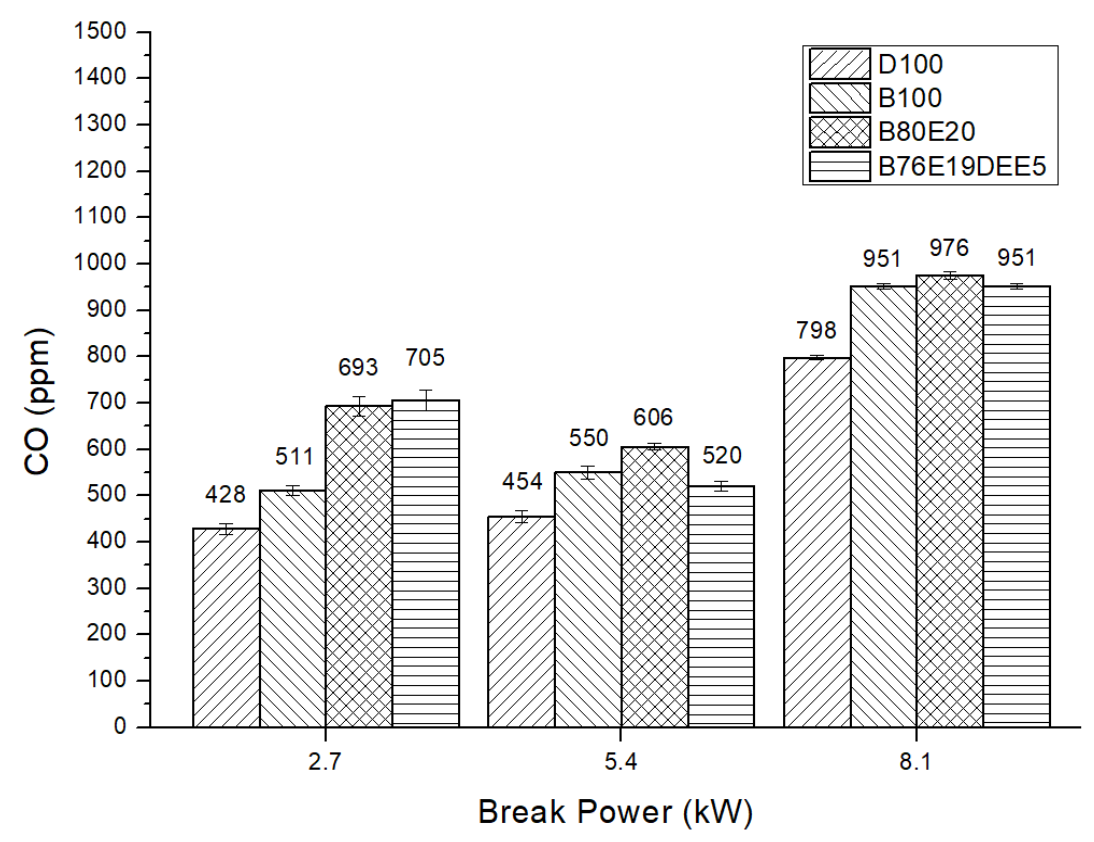

Figure 6. The variation of $\mathrm{CO}$ emissions with respect to the engine load.

The use of B100 increases CO emissions compared to D100 in about 20\%. This may be attributed to the lower air-fuel ratio and poor atomization that results due to biodiesel higher viscosity $[37,38]$. Some studies also indicate a reduction in CO emissions when the engine operates with biodiesel [27,31] as a result of the higher oxygen concentration. Blending ethanol with biodiesel (B80E20) considerably increased CO emission in comparison with B100 under all loads up to $35 \%$. This is attributed to the reduction in combustion temperature due to the high enthalpy of vaporization of ethanol [8]. This result is consistent with the result found in Çelik et al. [7]. The addition of DEE to biodiesel-ethanol blend produced a slight decrease in CO emission in comparison with B80E20, particularly under medium and high engine load. The higher cetane number and increased oxygen content of the B76E19DEE5 blend improve combustion efficiencies and decrease CO emission [39-41]. At $2.7 \mathrm{~kW}$, however, a slight increase was verified and has been attributed due to the decrease in combustion temperature as a result of both alcohol and DEE cooling effect into the blend.

\subsubsection{THC Emissions}

Total hydrocarbons emissions of the three engine operating loads (Figure 7) with blends of B80E20 and B76E19DEE5 were higher than those of D100 and B100.

The increase of THC emissions when ethanol is blended with diesel and biodiesel has been previously reported in the literature [35,42]. Emissions decreased with increasing engine loads for all tested fuels. This is due to the higher combustion temperature at higher loads that enhances combustion efficiency and thus reduces unburnt THC [43]. 


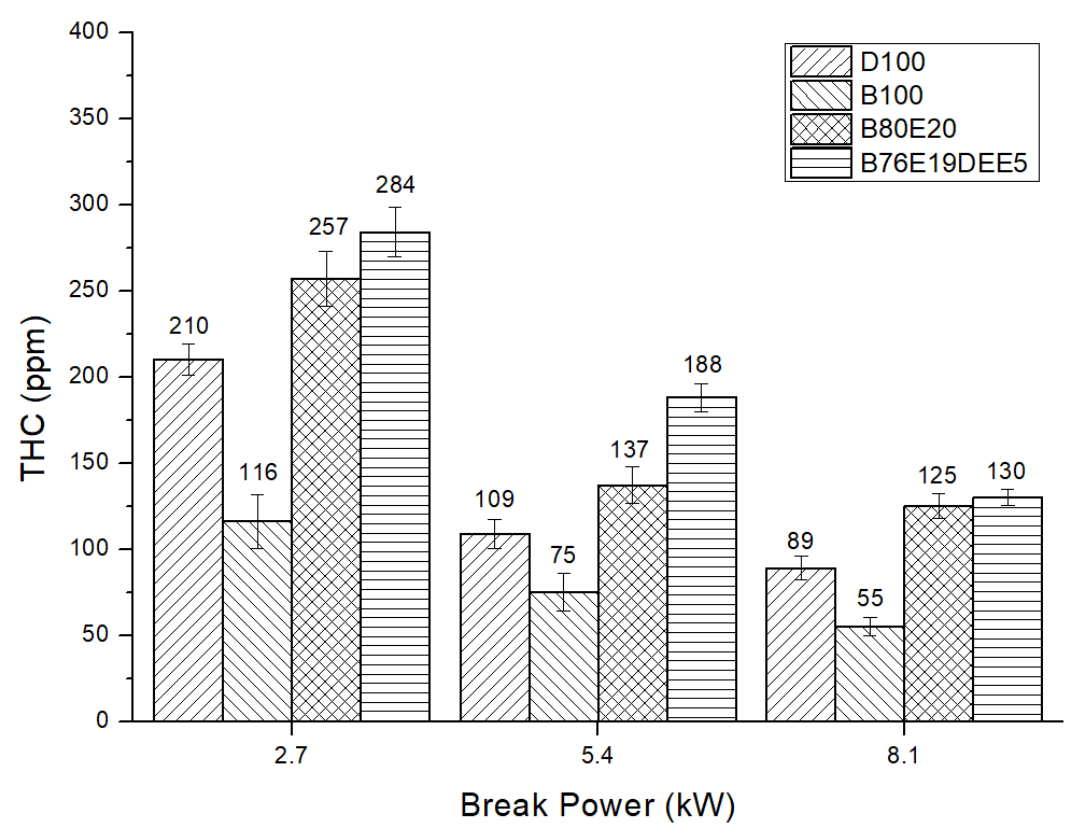

Figure 7. The variation of THC emissions with respect to the engine load.

The use of B100 shows significant reductions in THC emissions by $45 \%, 31 \%$, and $38 \%$ at $2.7 \mathrm{~kW}$, $5.4 \mathrm{~kW}$, and $8.1 \mathrm{~kW}$ loads, respectively, in comparison with D100. Among the factors responsible for the decrease in hydrocarbon emission is the higher $\mathrm{CN}$ and oxygen content of B100 since the oxygen contained in the fuel provides cleaner and more complete combustion related to D100. Besides, biodiesel combustion starts earlier in the combustion chamber due to its higher bulk modulus providing more time for mixture formation [44]. Similar results were previously reported in the literature $[45,46]$. B80E20 fuel shows an increase in THC emission compared to B100 and D100. Although the oxygen content in ethanol could increase the combustion quality, other properties have the opposite influence, such as lower $\mathrm{CN}$, lower LHV, and higher enthalpy of vaporization. The higher enthalpy of vaporization reduces combustion temperature, which influences the oxidation rate and THC formation [8,47]. The lower $\mathrm{CN}$ increases the ignition delay and decreases the total combustion time, which can increase the THC formation [45]. A reduction in LHV due to ethanol addition leads a higher amount of fuel injected per cycle, which also may favor THC formation [8].

The addition of diethyl ether to biodiesel-ethanol blend (B76E19DEE5) increased THC emission in comparison with the B80E20 blend. This result may be attributed to the high enthalpy of vaporization and high volatility of the blend when DEE was introduced, which reduces combustion temperature related to B80E20 [35,48].

\section{Conclusions}

Emissions, fuel consumption, and efficiency of a DI mechanical diesel engine coupled to a hydraulic dynamometer were measured using fossil diesel, biodiesel, biodiesel-ethanol (B80E20), and biodiesel-ethanol-diethyl ether (B76E19DEE5). Although BSFC increased with the use of biofuels due to the reduction in LHV, engine efficiencies increased with the use of B80E20 and B76E19DEE5, especially at medium and high loads. The higher oxygen content was appointed as the main reason for that improvement. In the case of the B76E19DEE5 fuel, the CN increased in comparison with B80E20, which further enhance the engine efficiency. Considering BSEC, the similarity of results shows that the performance of the proposed fuel blend was similar with the conventional diesel fuel, used in the original engine design. However, at the $8.1 \mathrm{~kW}$ load, B76E19DEE5 presented the lowest BSEC in relation to the other fuels tested. This lower BSEC was consistent with the highest engine efficiency in the same condition. 
The use of $\mathrm{B} 100$ increased $\mathrm{NO}_{\mathrm{x}}$ and $\mathrm{CO}$ emissions compared to $\mathrm{D} 100(1 \%$ and $20 \%$, respectively, on average), which was attributed to the higher viscosity of biodiesel. On the other hand, THC emissions decreased with the use of B100 due to the oxygen content in biodiesel, which provides a cleaner and more complete combustion when compared with D100. Addition of ethanol (B80E20) showed an increase in $\mathrm{NO}_{\mathrm{x}}$ emissions compared to $\mathrm{B} 100$ as well as compared to the other fuels. The results were attributed to the higher oxygen content and lower $\mathrm{CN}$ in the mixture. Considerable increases in $\mathrm{CO}$ and THC emissions were attributed to the high enthalpy of vaporization and lower LHV of ethanol. Finally, addition of DEE to biodiesel-ethanol blend (B76E19DEE5) generated significant reductions in $\mathrm{NO}_{\mathrm{x}}$ emissions. In comparison with B80E20 fuel, the reductions (3\% to $\left.13 \%\right)$ were attributed to the higher $\mathrm{CN}$ and the higher enthalpy of vaporization of the blend. At $5.4 \mathrm{~kW}$ and $8.1 \mathrm{~kW}$ loads, $\mathrm{NO}_{\mathrm{x}}$ emissions were the lowest among all tested fuels. Regarding $\mathrm{CO}$ emissions, the results showed reductions ( $3 \%$ to $14 \%$ ) in $5.4 \mathrm{~kW}$ and $8.1 \mathrm{~kW}$ loads, respectively, compared to B80E20 fuel. It was attributed to the higher $\mathrm{CN}$ and oxygen content of the blend. At $2.7 \mathrm{~kW}$ load, however, only a slight increase was verified. The THC emissions raised in comparison with B80E20 fuel up to 37\% at the high engine load. The results were attributed to the higher enthalpy of vaporization and by the elevated oxygen content of the B76E19DEE5 blend. No problems with engine stability were noticed using the blends proposed. This could be verified by low variation in the engine speed and at the values of torque acquisition.

It was clear in this work the positive effects of adding DEE in moderate concentration to the ethanol biodiesel mixture, in which there were slight increases in engine efficiency and reductions in $\mathrm{NO}_{\mathrm{x}}$ emissions.

Author Contributions: Conceptualization, M.C., J.S. and V.F.; Data curation, M.C.; Formal analysis, M.C., J.S., V.F., F.T., J.M. and E.T.; Funding acquisition, E.T.; Investigation, M.C.; Methodology, M.C., J.S., J.M. and V.F.; Project administration, M.C.; Resources, M.C. and E.T.; Supervision, J.M., V.F. and E.T.; Validation, M.C. and V.F.; Writing, M.C., J.M., V.F. and F.T.; Writing—review \& editing, M.C., F.T., J.S., V.F., J.M. and E.T. All authors have read and agreed to the published version of the manuscript.

Funding: This work had the financial support of Energy Laboratory of Bahia Federal University (UFBA) and CAPES (Coordination for the Improvement of Higher Education Personnel).

Acknowledgments: Energy Laboratory of Bahia Federal University (UFBA), Postgraduate Program in Industrial Engineering (PEI/ UFBA), and CAPES (Coordination for the Improvement of Higher Education Personnel). Authors also acknowledge PETROBAHIA for providing fuels to the work: diesel pure, biodiesel, and anhydrous ethanol fuels.

Conflicts of Interest: The authors declare no conflict of interest.

\section{References}

1. Mahbub, N.; Gemechu, E.; Zhang, H.; Kumar, A. The life cycle greenhouse gas emission benefits from alternative uses of biofuel coproducts. Sustain. Energy Technol. Assess. 2019, 34, 173-186. [CrossRef]

2. Ospina, G.; Selim, M.Y.E.; al Omari, S.A.B.; Ali, M.I.H.; Hussien, A.M.M. Engine roughness and exhaust emissions of a diesel engine fueled with three biofuels. Renew. Energy 2019, 134, 1465-1472. [CrossRef]

3. Khoobbakht, G.; Najafi, G.; Karimi, M.; Akram, A. Optimization of operating factors and blended levels of diesel, biodiesel and ethanol fuels to minimize exhaust emissions of diesel engine using response surface methodology. Appl. Therm. Eng. 2016, 99, 1006-1017. [CrossRef]

4. Noor, C.W.M.; Noor, M.M.; Mamat, R. Biodiesel as alternative fuel for marine diesel engine applications: A review. Renew. Sustain. Energy Rev. 2017, 94, 127-142. [CrossRef]

5. Garzón, N.N.A.; Oliveira, A.A.; Hartmann, M.R.; Bazzo, E. Experimental and thermodynamic analysis of a compression ignition engine operating with straight soybean oil. J. Braz. Soc. Mech. Sci. Eng. 2015, 37, 1467-1478. [CrossRef]

6. Ferreira, V.P.; Martins, J.; Torres, E.A.; Pepe, I.; De Souza, J.M.S. Performance and emissions analysis of additional ethanol injection on a diesel engine powered with a blend of diesel-biodiesel. Energy Sustain. Dev. 2013, 17, 649-657. [CrossRef] 
7. Çelik, M.; Örs, İ.; Bayindirli, C.; Demiralp, M. Experimental investigation of impact of addition of bioethanol in different biodiesels, on performance, combustion and emission characteristics. J. Mech. Sci. Technol. 2017, 31, 5581-5592. [CrossRef]

8. Venu, H.; Madhavan, V. Influence of diethyl ether (DEE) addition in ethanol-biodiesel-diesel (EBD) and methanol-biodiesel-diesel (MBD) blends in a diesel engine. Fuel 2017, 189, 377-390. [CrossRef]

9. Al-Esawi, N.; Al Qubeissi, M.; Kolodnytska, R. The impact of biodiesel fuel on ethanol/diesel blends. Energies 2019, 12, 1804. [CrossRef]

10. Al Qubeissi, M.; Al-Esawi, N.; Sazhin, S.S.; Ghaleeh, M. Ethanol/gasoline droplet heating and evaporation: Effects of fuel blends and ambient conditions. Energy Fuels 2018, 32, 6498-6506. [CrossRef]

11. Al-Esawi, N.; Al Qubeissi, M.; Whitaker, R.; Sazhin, S.S. Blended E85-Diesel fuel droplet heating and evaporation. Energy Fuels 2019, 33, 2477-2488. [CrossRef]

12. Tutak, W.; Jamrozik, A.; Pyrc, M.; Sobiepański, M. A comparative study of co-combustion process of diesel-ethanol and biodiesel-ethanol blends in the direct injection diesel engine. Appl. Therm. Eng. 2017, 117, 155-163. [CrossRef]

13. Yilmaz, N. Performance and emission characteristics of a diesel engine fuelled with biodiesel-ethanol and biodiesel-methanol blends at elevated air temperatures. Fuel 2012, 94, 440-443. [CrossRef]

14. Prbakaran, B.; Viswanathan, D. Experimental investigation of effects of addition of ethanol to bio-diesel on performance, combustion and emission characteristics in CI engine. Alex. Eng. J. 2018, 57, 383-389. [CrossRef]

15. Kandasamy, S.K.; Selvaraj, A.S.; Rajagopal, T.K.R. Experimental investigations of ethanol blended biodiesel fuel on automotive diesel engine performance, emission and durability characteristics. Renew Energy 2019, 141, 411-419. [CrossRef]

16. Ibrahim, A. Investigating the effect of using diethyl ether as a fuel additive on diesel engine performance and combustion. Appl. Therm. Eng. 2016, 107, 853-862. [CrossRef]

17. Lee, S.; Kim, T.Y. Performance and emission characteristics of a DI diesel engine operated with diesel/DEE blended fuel. Appl. Therm. Eng. 2017, 121, 454-461. [CrossRef]

18. Qi, D.H.; Chen, H.; Geng, L.M.; Bian, Y.Z. Effect of diethyl ether and ethanol additives on the combustion and emission characteristics of biodiesel-diesel blended fuel engine. Renew Energy 2011, 36, 1252-1258. [CrossRef]

19. Jeevanantham, A.K.; Nanthagopal, K.; Ashok, B.; Al-Muhtaseb, A.H.; Thiyagarajan, S.; Geo, V.E.; Ong, H.C.; Samuel, K.J.; Chyuan, O.H. Impact of addition of two ether additives with high speed diesel- Calophyllum Inophyllum biodiesel blends on $\mathrm{NO}_{x}$ reduction in CI engine. Energy 2019, 185, 39-54. [CrossRef]

20. Heywood, J.B. Internal Combustion Engine Fundamentals; McGraw-Hill: New York, NY, USA, 1988.

21. Du, E.; Cai, L.; Huang, K.; Tang, H.; Xu, X.; Tao, R. Reducing viscosity to promote biodiesel for energy security and improve combustion efficiency. Fuel 2018, 211, 194-196. [CrossRef]

22. Hulwan, D.B.; Joshi, S.V. Performance, emission and combustion characteristic of a multicylinder DI diesel engine running on diesel-ethanol-biodiesel blends of high ethanol content. Appl. Energy 2011, 88, 5042-5055. [CrossRef]

23. Veinblat, M.; Baibikov, V.; Katoshevski, D.; Wiesman, Z.; Tartakovsky, L. Impact of various blends of linseed oil-derived biodiesel on combustion and particle emissions of a compression ignition engine-A comparison with diesel and soybean fuels. Energy Convers. Manag. 2018, 178, 178-189. [CrossRef]

24. Duda, K.; Wierzbicki, S.; Śmieja, M.; Mikulski, M. Comparison of performance and emissions of a CRDI diesel engine fuelled with biodiesel of different origin. Fuel 2018, 212, 202-222. [CrossRef]

25. Elkelawy, M.; Bastawissi, H.A.-E.; Esmaeil, K.K.; Radwan, A.M.; Panchal, H.; Sadasivuni, K.K.; Ponnamma, D.; Walvekar, R. Experimental studies on the biodiesel production parameters optimization of sunflower and soybean oil mixture and DI engine combustion, performance, and emission analysis fueled with diesel/biodiesel blends. Fuel 2019, 255, 115791. [CrossRef]

26. Seraç, M.R.; Aydın, S.; Yılmaz, A.; Şevik, S. Evaluation of comparative combustion, performance, and emission of soybean-based alternative biodiesel fuel blends in a CI engine. Renew. Energy 2020, 148, 1065-1073. [CrossRef]

27. Lapuerta, M.; Armas, O.; Rodríguez-Fernández, J. Effect of biodiesel fuels on diesel engine emissions. Prog. Energy Combust. Sci. 2008, 34, 198-223. [CrossRef]

28. Palash, S.M.; Masjuki, H.H.; Kalam, M.a.; Masum, B.M.; Sanjid, A.; Abedin, M.J. State of the art of $\mathrm{NO}_{\mathbf{x}}$ mitigation technologies and their effect on the performance and emission characteristics of biodiesel-fueled Compression Ignition engines. Energy Convers. Manag. 2013, 76, 400-420. [CrossRef] 
29. Wei, L.; Cheung, C.S.; Ning, Z. Effects of biodiesel-ethanol and biodiesel-butanol blends on the combustion, performance and emissions of a diesel engine. Energy 2018, 155, 957-970. [CrossRef]

30. Abed, K.A.; Gad, M.S.; el Morsi, A.K.; Sayed, M.M.; Elyazeed, S.A. Effect of biodiesel fuels on diesel engine emissions. Egypt. J. Pet. 2019, 28, 183-188. [CrossRef]

31. Song, J.; Zello, V.; Boehman, A.L.; Waller, F.J. Comparison of the impact of intake oxygen enrichment and fuel oxygenation on diesel combustion and emissions. Energy Fuels 2004, 18, 1282-1290. [CrossRef]

32. Rahman, M.A.; Aziz, M.A.; Ruhul, A.M.; Rashid, M.M. Biodiesel production process optimization from Spirulina maxima microalgae and performance investigation in a diesel engine. J. Mech. Sci. Technol. 2017, 31, 3025-3033. [CrossRef]

33. Rajkumar, S.; Thangaraja, J. Effect of biodiesel, biodiesel binary blends, hydrogenated biodiesel and injection parameters on $\mathrm{NO}_{x}$ and soot emissions in a turbocharged diesel engine. Fuel 2019, 240, 101-118. [CrossRef]

34. Aydin, H.; Ilkiliç, C. Effect of ethanol blending with biodiesel on engine performance and exhaust emissions in a CI engine. Appl. Therm. Eng. 2010, 30, 1199-1204. [CrossRef]

35. Jamrozik, A. The effect of the alcohol content in the fuel mixture on the performance and emissions of a direct injection diesel engine fueled with diesel-methanol and diesel-ethanol blends. Energy Convers. Manag. 2017, 148, 461-476. [CrossRef]

36. Gharehghani, A.; Mirsalim, M.; Hosseini, R. Effects of waste fish oil biodiesel on diesel engine combustion characteristics and emission. Renew. Energy 2017, 101, 930-936. [CrossRef]

37. Xue, J.; Grift, T.E.; Hansen, A.C. Effect of biodiesel on engine performances and emissions. Renew. Sustain. Energy Rev. 2011, 15, 1098-1116. [CrossRef]

38. Santos, T.B.; Ferreira, V.P.; Torres, E.A.; Julio, A.M.; Ordonez, J.C. Energy analysis and exhaust emissions of a stationary engine fueled with diesel-Biodiesel blends at variable loads. J. Braz. Soc. Mech. Sci. Eng. 2017, 39, 3237-3247. [CrossRef]

39. Paul, A.; Bose, P.K.; Panua, R.; Debroy, D. Study of performance and emission characteristics of a single cylinder CI engine using diethyl ether and ethanol blends. J. Energy Inst. 2015, 88, 1-10. [CrossRef]

40. Beatrice, C.; Avolio, G.; Del Giacomo, N.; Guido, C.; Lazzaro, M. The effect of "Clean and Cold" EGR on the improvement of low temperature combustion performance in a single cylinder research diesel engine. $S A E$ Tech. Pap. 2008. 2008-01-650.

41. Sukjit, E.; Herreros, J.M.; Dearn, K.D.; García-Contreras, R.; Tsolakis, A. The effect of the addition of individual methyl esters on the combustion and emissions of ethanol and butanol -diesel blends. Energy 2012, 42, 364-374. [CrossRef]

42. Júnior, L.C.S.S.; Ferreira, V.P.; da Silva, J.A.M.; Torres, E.A.; Pepe, I.M. Oxidized biodiesel as a cetane improver for diesel-biodiesel-ethanol mixtures in a vehicle engine. J. Braz. Soc. Mech. Sci. Eng. 2018, 40, 79.

43. Shamun, S.; Belgiorno, G.; di Blasio, G.; Beatrice, C.; Tunér, M.; Tunestal, P. Performance and emissions of diesel-biodiesel-ethanol blends in a light duty compression ignition engine. Appl. Therm. Eng. 2018, 145, 444-452. [CrossRef]

44. Caresana, F. Impact of biodiesel bulk modulus on injection pressure and injection timing the effect of residual pressure. Fuel 2011, 90, 477-485. [CrossRef]

45. Lahane, S.; Subramanian, K.A. Effect of different percentages of biodiesel-diesel blends on injection, spray, combustion, performance, and emission characteristics of a diesel engine. Fuel 2015, 139, 537-545. [CrossRef]

46. An, H.; Yang, W.M.; Li, J.; Zhou, D.Z. Modeling analysis of urea direct injection on the $\mathrm{NO}_{\mathrm{x}}$ emission reduction of biodiesel fueled diesel engines. Energy Convers. Manag. 2015, 101, 442-449. [CrossRef]

47. Çelebi, Y.; Aydın, H. An overview on the light alcohol fuels in diesel engines. Fuel 2019, $236,890-911$. [CrossRef]

48. Rakopoulos, D.C.; Rakopoulos, C.D.; Giakoumis, E.G.; Papagiannakis, R.G.; Kyritsis, D.C. Influence of properties of various common bio-fuels on the combustion and emission characteristics of high-speed DI (direct injection) diesel engine: Vegetable oil, bio-diesel, ethanol, n-butanol, diethyl ether. Energy 2014, 73, 354-366. [CrossRef]

(C) 2020 by the authors. Licensee MDPI, Basel, Switzerland. This article is an open access article distributed under the terms and conditions of the Creative Commons Attribution (CC BY) license (http://creativecommons.org/licenses/by/4.0/). 